\title{
Preparing a Two Column Paper with MS Word for Windows
}

\author{
Yuan Chun \\ Department of English, Tangshan College, Tangshan 063000, China
}

\begin{abstract}
At present, most colleges and universities in China use multimedia and network to aid English Teaching. But some problems exist in college English teaching with the help of the multimedia and network. In order to improve the efficiency of classroom teaching this article analyzes several aspects of these problems such as the use of multimedia, the relationship between different elements of teaching and students' motivation, then puts forward some countermeasures.
\end{abstract}

KEYWORD: College English Teaching; Multimedia Network Technology; Problems, Countermeasures

\section{GENERAL INSTRUCTIONS}

At present, most colleges and universities in China use multimedia and network to aid English Teaching. It is to improve the efficiency of classroom teaching and plays an important role in enhancing the students' interest in learning. However, with the development of multimedia and network technology there are some problems in the implementation of college English teaching, which had a negative impact on the quality of teaching to which we should pay more attention.

\section{PROBLEMS}

\subsection{Partially pursuing the effect of courseware and ignore the needs of students}

The proper use of multimedia technology can greatly increase the students' interest. Therefore, some teachers think courseware should be fancier. The more attractive the courseware, the better is teaching effect. However, Clark's research shows that, in the multimedia environment, students expressed interest, excitement and curiosity. But with their familiarity with the environment the interest, excitement, curiosity expressed by students will gradually subside. Therefore, the charm of multimedia is short. To enable students to learn more knowledge, the key lies in teaching content. But some teachers spend more time in preparing lessons rather than knowledge. They make very beautiful courseware where there are both interesting video and exquisite pictures. Some teachers even treat multimedia as a form of entertainment. In this way, English class is very relaxing where students can appreciate the courseware enjoyably, but did not achieve anything useful.

\subsection{Relying on multimedia excessively and ignoring the role of Teachers}

Teaching in a multimedia classroom includes many factors such as students, teachers, teaching content and teaching media. In a class, multimedia technologies should be used reasonably. However, in the classroom some teachers play their prepared multimedia courseware all the time. And the students are their audience. There are neither interactions between teachers and students nor human-computer interactions. This kind of teachers cannot play a leading role in learning. Effective teaching lies in the teachers' inspiring questions for the students to think about actively. What's worse, it completely ignored the students as the masters of learning. It makes students accept knowledge pessively and cannot be independent thinkers. Their ability to discover and solve problems cannot be enhanced. Besides, what they hear in the class have subtitles, which makes them bored quickly.

\subsection{Students' lack of initiatives to learn in the network environment}

Many students are used to the traditional teaching method and relying on their teachers. They feel uncomfortable with the multimedia network teaching mode that has a large amount of 
information. In the network environment, the students are confused. Without the guidance of their teachers, they don't know what the key is. They have no sense of achievement after learning. More importantly, it requires students to have a great deal of self-control and binding in network learning environment without the teachers' supervision because there are too rich teaching resources in the network space. Students should choose their own learning content according to their own needs. The learning time is also more flexible. To make students really become the master of learning, teachers should give them guidance and help them adapt to the new learning mode.

\subsection{Teachers' lack of proficiency in using multimedia and network facilities}

Many teachers are not very proficient in making the use of modern multimedia devices and network facilities, so that they often make mistakes in the class when using these aids. For example, they sometimes fail to play the courseware. Sometimes the computer crashes. In the case of emergency, they cannot deal with the problems with the multimedia timely. Then they will have to ask the lab managers for help. Thus they not only delay the process of teaching, but also they will waste the precious time of students. What's worse, the failure in using the modern multimedia devices will badly affect their images among their students.

\section{ANALYSIS OF COUNTERMEASURES}

Multimedia network technology is an advanced teaching method. It realizes the transition from teacher centered mode to student-centered. It helps to cultivate students' ability of using language and the ability of learning by themselves. How to play the advantages of multimedia, arouses the students' interest in language learning and to make the most of classroom teaching has become a problem that many university English teachers need to think about and practice.

\subsection{Multimedia courseware --- supplementary means of teaching}

Practical educational psychology finds that students' ability to accept information is limited. Too much information will distract their attention and is not helpful for the students to accept useful information. Therefore, teachers should not spend too much time making fancy courseware and cram listening, reading, writing and speaking contents all in a courseware. Also, they should not use the courseware attached to the text books in classroom teaching directly. Rather, they should design their own courseware according to the reception ability of the students. In the process of teaching, teachers should control the amount of information, abandon the flashy content and focus on the key points and difficulties.

\subsection{Handling the relationship between the various elements of the teaching activities properly}

Multimedia classroom teaching includes many factors such as students, teachers, teaching content and teaching media. In a class, multimedia technology should be used based on the reasonable proportion. First of all, teachers should be aware that multimedia is only a supplementary means, and teaching activity should be conducted through the exchange of thought, emotion and information between teachers and students. Teachers should use multimedia technology properly and the whole class should not be carried on with multimedia only, because the multimedia technology cannot replace enlightening questions that guide students to think about problems and explore solutions. Secondly, teachers should realize that the students are the master of learning practice and the teachers are like the guides. The teaching task should also be changed from giving good lectures to helping students make study plans, providing targeted learning resources and organizing activities according to students' different characters and levels of English. Also students should change the traditional learning attitude towards English learning. In the beginning of the semester, teachers should introduce the new teaching mode comprehensively and systematically in order to make the students have a better understanding of the modern network technology used in teaching, especially in viewing, listening and speaking. Teachers should arrange the teaching content based on students and all the teaching activities are around the students.

\subsection{Strengthening the training of teachers and improve the teachers' ability}

Good teaching model cannot do without teachers with novel teaching ideas that pay attention to research and improve the teaching method. The teacher should be guided with modern teaching ideas to promote the university English teaching, thus improving the quality of teaching. Therefore, the authorities that are in charge of teaching should pay attention to the training of teachers. First, they should send teachers to participate in training network and multimedia technology regularly. Without the teachers and students who can use the multimedia and network technology effectively multimedia network teaching cannot be conducted smoothly. Because if teachers are not familiar with modern multimedia and network technology and 
cannot handle the unexpected situations in the class they will not only waste the precious time, but also affect the teaching. Information era requires the teachers should not only have the ability to use the Internet skillfully but also have skills to screen and access to information. Also they should have the ability to processing and process information creatively and use it in teaching English. Secondly, in addition to consolidate professional knowledge, the teachers also should study more in other fields of knowledge. In the network age, the teachers and the students are on the same starting line. They can find the latest knowledge on the Internet, talk about many new things which is open and have no fixed answers. Therefore, teachers should continuously explore more information, and strive to own great insight into new things. Only in this way can they guide the teaching process.

\subsection{Establishing the student-centered teaching mode of human-computer interaction.}

Human-computer interactive teaching mode refers to the combination of multimedia or online learning with classroom teaching. In the network environment, the teachers should help students to cultivate a good habit of learning by themselves. Teachers should let them understand the difference between university learning and traditional teaching mode adopted by high schools as soon as possible. Teachers should provide different learning materials according to different students and help them make study plans. For students, they are organized by the teachers to participate in group activities. For example, teachers can organize classroom activities and discussions. Teachers guide the study and help students grasp the keys to enable students to learn by themselves effectively. By asking questions and checking students' learning on line teachers solve students' problems, summarize the main points and difficulties. While the learning is completed by the students themselves, students can learn by themselves according to their own needs and level and with the guidance of teachers via Internet or multimedia courseware. Students review what they learn and feedback their learning progress to the teachers timely. At the same time, teachers should strengthen the regulation of students. With the use of online instant messaging, e-mail and other means teachers can know about students learning timely.

\section{CONCLUSION}

In short, the advent of the Internet age changes every aspect of our lives. College English teachers should keep pace with the times and change their teaching philosophy to implement and promote the threedimensional model of English teaching based on network and multimedia technology Although there are some problems in the present multimedia network teaching inevitably, with the continuous development of the multimedia technology and the emergence of more and more excellent English teachers, multimedia network teaching will give full play to its advantages.

\section{REFERENCES}

[1] Cook, V. Second Language Learning and language Teaching. Beijing: Foreign Language Teaching and Research Press, 1996.

[2] Davies, P. \& Pearse, E. Success in English Teaching. Shanghai: Shanghai Foreign Language Education Press, 2002.

[3] Su Huom Adam galinsky. Advice to Teachers. Beijing: Education and Science Publisher, 2000.

[4] Shu Dingfang Foreign language Teaching: Problems and Countermeasures. Shanghai: Shanghai Foreign Language Education Press, 2004.

[5] Hu Long. Computer-aided Language Teaching. Shanghai: Shanghai Foreign Language Education Press, 2002.

[6] Xiao-ling Shi. Multimedia Computer and the Reform of the Teaching of English Writing. Foreign Language World, 2008, (4): $41 \sim 47$.

[7] Zhao Rong. English Game Teaching Based on the Feasibility of the Digital Model. Journal of Electrochemical Education Research, 2009, (6): 113 116.

[8] Lou Heying etc. A Study on the Teaching of Writing with the Use of Online Tutoring and BBS. Foreign Language World, 2008, (4): $41 \sim 47$. 